\title{
Efforts to Elevate Al-Quran Studyamong the Visually Impaired Group in Malaysia: Challenges and Proposals
}

\author{
Tengku Intan Zarina Tengku Puji \\ Ahmad Yunus Mohd Noor
}

Siti Nur Azimah Sabaruddin

Faculty of Islamic Studies, National University of Malaysia, Bandar Baru Bangi, Selangor, Malaysia tengkuintan97@yahoo.com.my

\section{Doi:10.5901/mjss.2015.v6n6s5p419}

\section{Abstract}

Reciting and familiarization with al-Qur'an is very much urged on the Muslim ummah, whether they are typical or disbled people. Based on innovative research and current technological advances, it is now possible to provide this opportunity and facilities of education, including in al-Quran studies, to visually impaired people. There are some previous research and innovations, including the invention of a portable electronic panel known as Electronic Braille (e-Braille) al-Quran Teaching Aid (N.A.Abdul Khoni 2010), research on vibration of al-Quran in Braille code (Abdallah M.Abualkhishik (2010) and research through Google Speech API (Samir, 2013). This research proves that al-Quran studies among the visually impaired are increasingly gaining the attention of many parties, especially among the academicians. In Malaysia the Special Education program implemented for the visually impaired is part of the National Education Policy. However, this program poses certain challenges for secondary schools in Malaysia, including the issues of infrastructural needs in support of teaching and learning of Islamic Education and the lack of teaching aids from extensive sources. The course module materials for al-Quran teaching in Braille are too scanty and textbooks for Islamic Education are not in Braille. A paradigm shift is required to overcome the challenges, particularly involving social engagements of smart partnerships among the authorities. Malaysia should emulate the excellent examples of other Muslim countries in dealing with issues involving the visually impaired, such as Jordan which was awarded the Franklin Delano Roosevelt International Disability Award for her success in placing issues of the disabled at the top of the national agenda. The "investment in humanity" policy which is an effort to compete with resource-rich neighbouring countries explains how Jordan is able to solve the needs of her disabled in comparison to her neighbours (Muslim World Issue, 2006). Meanwhile Iran has succeeded in publishing and distributing copies of Quran in Braille to other countries through the application of new technology. This Braille Quran is recognized as the best during the Braille Quran International Seminar in Turkey. Hence the purpose of this article is to discuss several important solutions to elevate al-Quran studies among the visually impaired in Malaysia.

Keywords: Quran studies, Braille, Special Education, challenges

\section{Introduction}

Al-Quran studies undoubtedly play an important role in developing the Ummah. Hence, al-Quran studies need to be given due attention and focus in national education development in order to ensure the best impact on the process of building the Ummah. Even so, not every Muslim is blessed with good eyesight to study al-Quran. There are those who are congenitally blind or have lost their total or partial eyesight from accident or mishap. Such special needs people may only hear the holy verses recited before committing them to memory. As for those with a strong memory, they may memorize all 30 chapters of al-Qur'an. Visually impaired people are also human beings created by Allah SWT to worship Him. Thus, even though they may be handicapped in terms of sight, they also have needs and are similarly obliged to learn and glorify al-Quran as other Muslims. Hence, Braille Quran is the best solution for them to learn al-Qur'an and understand it.

Islamic history shows that al-Quran has given a respectable career to the visually impaired in the Muslim world. Many among them have completed memorization of al-Qur'an and made a career being a Qari (Quran reciter), for which there is a good market (M.Abdel Haleem, 2001). A Qari is not only needed at funerals, commemorative ceremonies, Maulid (Prophet Pbuh) processions but also for Quran weekly activities at home. Likewise, a Qari is needed on the opening of new buildings and events such as seminars. History also shows that each mosque had a permanent Qari. In fact, technological development enables recitations to be recorded on tape and video, and the opportunity to be an 
international Qari.

\section{Efforts to Elevate Al-Quran Studies among the Visually Impaired Disabled in Malaysia}

In Malaysia, Braille Quran was first taught in the year 1952 at Princess Elizabeth Special Education National School, Johore Baru. In the decade of 50-60's, efforts were focused on introducing in Braille, the basic hijaiyyah letters, vowel signs and so on. Through the Malaysian Society for the Blind, the project Braille Quran was launched in the year 1980 and funded by an Islamic Welfare Organization, PERKIM. This project took 5 years to complete and succeeded in producing two master copies, in Arabic and Malay languages. This special needs group was never marginalized in the world of education. It is proven in the inclusion of the Department of Special Education in the National Education Philosophy. Special education is also provided for school students (Education Act, 1996) A special school is one which provides special education as specified by the regulations under Section 41 of Education Act In school, the visually impaired group may learn more formally as does the typical group. Further, in the year 1983 the Ministry of Education had set up a Committee for al-Quran al-Karim Braille Code with the purpose of creating a consistent and systematic code to produce and learn al-Quran in Braille in Malaysia. This effort took 15 years and finally a Wasilah Braille Code for recitation of al-Quran al-Karim began to be printed by Dewan Bahasa dan Pustaka (DBP) in the year 1998.

The fate of the visually impaired disabled gained increasing attention of various parties in the government, NGO and volunteers. Efforts and interest to help this group through the establishment of more schools at once recognizes the efforts of volunteers until the materialization of Implementation of Education Policy under Declaration 169 (Mustaffa Abdullah 2010). Next in the year 2013, the Department of Islamic Development of Malaysia (JAKIM) in collaboration with Islamic Sciences University of Malaysia (USIM) and NGO of the visually impaired succeeded in developing the method of Standard Writing of Braille Quran Malaysia based on Rasm Uthmani and is expected to be published sometime this year 2015 (Noor Najihan and Kauthar, 2008) Jakim through its Publication Section has succeeded in holding a workshop, Development of Standard Writing of Braille al-Quran of Malaysia, comprising of representatives of USIM, Ministry of Interior (KDN), Society for the Visually Impaired of Malayisa (PERTIS), Organization for Development of the Blind Malaysia (PPOBM), Braille Society of Malaysia (PBM) and JAKIM. Muslim visually impaired special people also have the same instinct to learn al-Quran as typical Muslims. Hence, various steps have been taken by the authorities and NGOs to elevate al-Quran studies in Braille among the visually impaired disabled, such as the giving of free copies of Braille Quran, holding classes for learning Braille Quran, holding events for recital (musabaqah tilawah) of al-Quran for these special people and conducting related academic research.

\subsection{Free copies of Al-Quran in Braille}

Al-Quran in Braille is mushaf of al-Qur'an which uses the Arabic in Braille code to represent hijaiyyah letters, vowel signs such as fathah, dammah, and kasrah as well as symbols of shaddah, sukun, mad and so on (Ahmad Kamel et.al 2009). It is written and read from left to right, letters and vowel signs are written together, that is, letters are marked with vowel signs, and only shaddah sign is written before a letter. Braille Quran is specifically created for the visually impaired to read al-Quran. Technological advances have enabled the blind to read al-Quran in Braille created for them. This system of raised dots is benefitting the Muslims among the visually impaired. Many of them are able to learn al-Quran on their own without assistance. However, the dream to read al-Quran in Braille is only achievable for those who can afford it as the edition costs between RM200-300 per copy (Siti Maisarah, 2011). As it is expensive, not every visually impaired person can afford to purchase a copy. Thus, the generosity of parties who give free copies of Braille Quran is a blessing for which those in need of it are grateful. Among those who have come forward to give this assistance are PERTIS, POBM, State Islamic Councils, NGO, social activists and generous philanthropists.

In Malaysia, the development of Braille Quran was initiated by the Society of Visually Impaired Muslims of Malaysia (PERTIS) and it is the only organization which has been entrusted by the first copyist of Braille Quran in soft copy, Muhammad Lee Abdullah, to implement publication and printing of Braille Quran in the beginning from the year 1998. The Braille Quran was then verified by JAKIM and approved by the KDN. According to the Deputy President of PERTIS, Zamzuri Ghani, each Ramdan month, the society receives many orders for Braille Quran, including for nation-wide distribution to the disabled, in addition to contributions for mosques or those in need of it. Clearly, Braille Quran is sold at the price of RM200 but usually for PERTIS members who are visually impaired disabled, it is given free of charge. It is the aspiration of PERTIS to give away a copy of Braille Quran free to every blind person so that they may be knowledgeable about al-Quran (Siti Airunnisa Alaui. 2015). According to Puan Seri Norma Hashim, a social activist, many among the visually impaired cannot afford to own a Braille Quran. Hence, she feels the call to donate copies of Braille Quran to 
those who need it (Fatin Hafizah Mohd Shahar. 2014).

In addition, there are other NGOs such as al-Fitrah Foundation which is a branch of International Union of Braille Quran Services (IBQS) in Malaysia. This body mobilized the Braille Quran Initiative such as encouraging public contribution through purchase of al-Quran for the visually impaired. They also print Muqaddam and Surah Yasin other than al-Qur'an for the visually impaired to use. This pro-active attitude is clearly seen in efforts to share quality information such as readers, reports of Braille Quran seminars, Tafseer project and so on (www.braillemalaysia.com). This year, IBQS will be hosting the Second International Meeting on Braille Quran in Istanbul from 24th to 29th August, 2015. The event will be opened with an inaugural ceremony where Turkish officials will be participating. The inaugural ceremony will be followed by the academic part of the event. This year our academic partner is Yalova University, Faculty of Islamic Sciences. The academic part will cover 3 academic papers and a key-note speech by a very well-known professor in the area of Islamic Sciences. The title of the academic part this year is "Understanding the Concept of Disability in the light of the Holy Quran".(www.kitaba.org)

The Malaysian government is increasingly active in efforts to improve religious education among the disabled group and such efforts show positive development. In Malaysia, there are some states which hold Braille Quran classes. These classes are organized by PERTIS. To date, the states of Terengganu, Kelantan, Pahang, Kuala Lumpur, Negeri Sembilan, Kedah and Perlis are involved in the program of Braille Quran studies (Siti Nor Azimah, 2014).

Braille Quran class is for the purpose of giving exposure to the method and technique of reading Braille al-Quran for the visually impaired. Braille al-Quran has certain codes which have to be learnt and memorized before reading it. In order to realize this effort, the Trengganu State Religious and Malay Customs Council (MAIDAM) allocated an annual amount of RM285000 for the disabled to study Braille. The MAIDAM Senior Director, Department of Dakwah, Education and Mosque Management, Datuk Samsiah Awang said that the provision is channelled directly to PERTIS Trengganu which is responsible for managing the class thrice a week at Seberang Takir. So far, almost 50 students have benefitted from these classes which are well-received by the disabled throughout the state. In Kuala Lumpur, PERTIS holds classes for its members every Saturday or Sunday at the building of the Malayisan Organization of the Blind (MAB), Brickfields. Membership has reached 70 blind persons (Noradila Mahamad. 2014).

\section{2 al-Quran Tilawah Event}

Efforts to elevate proper reading of al-Quran by the visually impaired are intensified through the organizing of the Braille al-Quran Tilawah Event. Such an event gives the opportunity to this special group to participate in it. For Norasyikin Baharudin, 36, being visually impaired is not an obstacle to recite al-Quran. She never missed participating in the Braille al- Quran Tilawah Event organized by the Department of Social Welfare (JKM). The Director of Negeri Sembilan JKM, Abdullah Hanafi said that the purpose of the program is to attract the interest to read, understand and familiarize with alQuran as well as inculcate Islamic values and Islamic practice of entertainment (Sinar Harian, 2013).

Being visually impaired also did not hinder Mohd. Qayyim Sarimin, 14, from clinching the championship thrice in a row in the al-Quran Tilawah category of the 2013 National Level Interschool al-Quran Tadarus Event (MTQSS). Congenitally blind Qayyim, who represented the state of Kelantan and recorded a meaningful success, has participated in the annual program since the year 2010 (Mohd Naim Aziz. 2013). His success which has made him the pride of the special needs people, proves that Braille al-Quran facilitates this special needs group to acquire worldly knowledge as well as of the hereafter so long as they do not feel marginalized or disadvantaged by their handicap. This is because. Allah SWT gives them a special place in addition to manifold reward if they are sincere in their devotion to Him.

\subsection{Conduct Study and Research}

There is much research concerning Braille al-Qur'an Braille in Malaysia. One of these is a modular study by Muhammad Mustaqim Mohd Zarif et al (2014) entitled Towards an Uthmanic Model of Quran Orthography in Braille. The aim of his paper is to propose an Uthmanic model of Quranic orthography in Braille. It focuses on the chapter of Maryam as its sample and applies the qualitative methods of textual and comparative analysis on the revelational criteria of Quranic orthography and the limitations of the Braille writing system. This results in a more standardized and adaptable model of Quranic orthography in Braille with minimal changes in the use of vocalization and other diacritical marks of the Quran. Currently, this model is proposed to serve as a basis for the development of a national standard of Quranic orthography in Braille by the relevant authorities in cooperation with the visually challenged organizations in Malaysia. Another study is on the implementation of Braille Quran learning, Module of Teaching Braille al-Quran: A Preliminary Survey by Norhasrina Ibrahim (2014). Yet another is by Ahmad Nowawi et al (2002) entitled Implementation of Learning al-Quran 
using Braille Writing for Visually Impaired Students at Princess Elizabeth Special Education National School, Johor Bahru. This research focuses on three aspects: using teaching aids, achievement and method of teaching and learning. The research instrument used is questionnaire and findings show that use of teaching aids and method of teaching and learning play an important role in improving student achievement.

There is also a study concerning an instrument which aids in learning Braille Quran, by N.A.Abdul Khoni et al (2010) entitled A Novel Development of Electronic Braille al-Quran Teaching Aid. This research describes the development of a portable electronic panel that helps in teaching the visually impaired to learn and read Al-Quran, named Electronic Braille (eBraille) Al-Quran Teaching Aid. The eBraille Panel comprises of an outer case, Braille cell, jacks, Perkin keys, functionality keys, navigation keys and sound keys. The panel has an ergonomic characteristic that gives comfort to the user while using the panel. The panel is portable and it can be connected to a computer and the teaching process can be done by controlling on the computer or the panel itself. As the teacher types the character, it will be displayed to the student's panel via wireless connection. The main advantage of this research is to allow teaching the visually impaired in more effective ways. The delivery of lesson will be more efficient and the teaching and learning process can be done in just a short time.

Another study by Noornajihan Jaafar et al (2014) identifies the most qualifying characteristics of an educator (murabbi) for teaching special children. He outlines eight elements of the Murabbi model for special children: Rabbani thinking, mastery of knowledge and generous, positive personality, educates from the heart, possesses teaching skills, effective communication, self-motivation and continuous training and education. In another study, Norakyairee Mohd Raus et al (2013) analyzes current issues and challenges of teaching Braille. This research involves the instruments of observation and interview. Findings show that there are some issues and challenges which require the support of all parties in order for the concept of the beauty of religious living among Visually Impaired Special Needs Students (MBK) to succeed.

\section{Challenges and Proposals for Braille Quran Studies in Malaysia}

It is indeed undeniable that there are many challenges in Braille al-Quran studies in Malaysia. These challenges may be fundamental or ancillary. The fundamental issues involve teachers and classes, infrastructure and teaching aids. According K. A. Razhiyah (2010), there are also some teachers who volunteer to teach special education classes not because of interest, but only to flee from the mainstream workload. They assume that in Special Education classes there are not many tasks to do. He added that the syndrome of going back to their hometown, lack of option, and additional allowance, are reasons why some teachers are drawn to this field. It is not surprising there is a request to return to mainstream schools as a teacher or transfer due to academic exchange. This fact is supported in a study by Norhasnira Ibrahim et al (2014) which finds that the main problem faced by teachers is that they do not know basic Braille and alQuran Braille code because of no exposure during teacher training.

Al-Quran classes for typical people are numerous, but lacking for this special needs group. Only a few states provide Braille al-Quran classes. Infrastructure and needs for ths special group in mosques, particularly in the field of alQuran are seriously lacking, or can be said to be non-existent. There is no Braille al-Quran available in mosques for their use, no special al-Quran classes for them, no tajwid reference materials in Braille to facilitate their understanding of tajwid rules in order to master recitation of al-Quran or even any translation of al-Quran in Braille (Hajarul Bahti Zakaria et.al, 2015).

Likewise, Special Eduaction programs in secondary schools in Malaysia still lacks infrastructure to support teaching and learning of Islamic Education and Teaching Aids from extensive resources (Mohd Hanafi et.al 2009). The course module reference materials for teaching al-Quran in Braille writing are too scanty. Islamic Education textbooks are also not written in Braille in comparison to textbooks for other subjects. These limitations make it difficult for teachers and visually impaired students to implement the process of teaching and learning al-Quran. All these essential matters require due attention and focus in order to ensure continuance of dakwah towards the visually impaired group, particularly in the field of al-Quran studies.

Hence, in order that the problem may be resolved and pro-active steps may be taken, a few proposals are submitted below:

1. The authorities need to provide and increase teaching aids to encourage students so that they can make references on their own. Familiarization with al-Qur'an is highly demanded of the Muslim community whether they are typical or disabled groups. One study in the form of a social engagement to assist in this regard entitled "Pembinaan Modul Braille Hadis 40 Imam Nawawi : Ke Arah Memartabatkan Program Pendidikan Khas di Malaysia "(Constructing Braille Module of 40 Hadith by Imam Nawawi: Towards Elevating the Special 
Education Program in Malaysia) is conducted by researchers of the National University of Malaysia (UKM) and funded from FRGS/1/2014/SSI03/UKM/02/5. This research is a collaboration between UKM and PERTIS.

2. Innovative research and current technological advancement require scientists, particularly academicians, to fulfill the educational opportunities and facilities for the visually impaired group, including in al-Quran studies. One such research is by Abdallah M Abualkishik et al (2010) entitled "Quran Vibrations in Braille Code". The aim of his research is to build a system which translates Quranic surah into Braille symbols including new vibrations. The existing system is inadequate because there are no specific vibrations in reading al-Quran such as required for Izhar, Idgham, Ikhfa', Iqlab and Qalqalah. Hence, his research aims to build a system which translates specific vibrations into Braille symbols.

3. It is hoped that more NGOs and noble-hearted volunteers will come forward to help the visually impaired by providing facilities and other necessities, especially Braille al-Quran. This is because the Braille Quran is like a beacon of light for them to learn al-Quran. Datuk Mah Hassan Omar, President of the Braille Society of Malaysia hopes to give at least one copy of the Braille text of al-Quran free of charge to each family or place one in each mosque in the country. This is a challenge to the government, the private sector and society as a whole to think of their status and help this special needs group to acquire adequate knowledge (Siti Maisarah Sheikh Rahim, 2011).

\section{Acknowledgement}

This research working paper is part of the project funded by Fundamental Research Grant Scheme FRGS/1/2014/SSI03/UKM/02/5. "Module Construction of 40 Hadith by Imam Nawawi in Braille: Toward Elevating Special Education Program in Malaysia". This research involves researchers from National University of Malaysia (UKM), Bangi in social engagement with PERTIS.

\section{References}

Al-Qur'an

Abdallah M. Abualkishik \& Khairuddin Omar. (2010) Qur'an Vibrations in Braille Code, Georgian Electronic Sciences Journal (GESJ), Computer Sciences and Telecomunications, 3 (26), 18-30.

Ahmad Kamel Mohamed, M.Mustaqim M.Zarif, K.Anuar Mohamad, M.Alwi Yusoff. (2009). Method of Braille Quran Study. Research report USIM PPP 2005 . Nilai: USIM

Ahmad Nowawi, Mohd Rahmat, Safar \& Ajmain. (2002). "Implementation of Learning al-Quran using Braille Writing for Visually Impaired Students of Princess Elizabeth Special Education National School, Johore Baru". Thesis, Technology University of Malaysia.

Fatin Hafizah Mohd Shahar.( 2014), Berita Harian,Free Quran Braille. 22 December.

Hajarul Bahti Zakaria, Mohd Huzairi Awang @ Husain, Bani Hidayat Mohd Shafie, Nor Hayati Fatmi Talib. (2015). Dakwah Development Of the Visually Impaired Group: Highlights from the Historical Perspective of al-Quran Education. 4th Proceeding on International Conference of Teacher Education, Bandung, Indonesia 8-10 November.

M.Abdel Haleem. (2001). The Blind and the Qur'an. Journal of Quranic Studies, Edinburgh University Press, 3 (2), $123-125$.

Mohd Hanafi Mohd Yasin, Noraini Mohd Salleh, Hasnah Toran \& Mohd Mokhtar Tahar.(2009). Classroom Infrastructure for Special Education Integration Program in Support of Teaching and Learning Islamic Education. Islamic Education Discourse (7 edition) Gontor: Institute Islamic Research Darussalam, Indonesia, 540-546.

Muhammad Mustaqim Mohd Zarif, Abdul Qadir Umar Usman, Noorjihan Jaafar. (2014) Towards an Uthmanic Model of Quran Orthography in Braille, Global Journal al-Thaqafah (GJAT), June 4 (1) 29.

Mustaffa Abdullah.(2010). al-Quran Education among Visually Impaired People in Malaysia . Al-Bayan. Volume 8. Universiti Malaya, 2134.

N.A.Abdul Khoni, A.Robasan, Y.Abdullah, A.R.Musa, M.Z.Md Zain, M.S.Yaacob \& M.Hussein.(2010). A Novel Development of Electronic Braille Qur'an Teaching Aid, International Conference on Sciences \& Social research (CSSR), Dec.5-7 2010,Kuala Lumpur.

Norhasnira Ibrahim, Norakyairee Mohd Raus, Mohd Nur Adzam Rasdi, Noor Najihan Jaafar,Norazman Alias, Norullisza Khosim, Norzulaili Mohd Ghazali. (2014). "Braille al-Quran Teaching Module: A Preliminary Survey". Tajdid in Qur'anic Studies, Deparment of al-Qur'an \& al-Hadith, Academy of Islamic Studies, University of Malaya, 43-54.

Noor Najihan Jaafar \& Kauthar Andul Kadir. (2008). Braille Quran Education in Malaysia: History and Development. Conference on Heritage of al-Qur'an and Hadith in Archipelago. Universiti Malaya, Kuala Lumpur.

Noornajihan Jaafar, Norakyairee Mohd Raus, Nurul Asiah Fasehah Muhamad, Norzulaili Mohd Ghazalid, Robiatul Adawiyah Mohd@Amat, Syed Najihuddin Syed Hassan, Mahyuddin Hashim, Ab.Halim Tamuri, Norshidah Mohamed Salleh \& Mohd Isa Hamzah. (2014). Quran Education for Special Children: Teacher as Murabbi. Creative Education, 5,435-444.

Norhasrina Ibrahim 2014. Braille Quran teaching Module: A Preliminary Survey. Tajdid in Quranic Studies, Deparment of al-Qur'an \& alhadith, Academy of Islamic Studies, University of Malaya, 43-54. 
Norakyairee Mohd Raus ,Mohd Nur Adzam Rasdi, Norazman Alias, Norhasnira Ibrahim, Norullisza Khosim, Noornajihan Jaafar, Ab Halim Tamuri,Norshidah Salleh dan Hajarul Bahti Zakaria (2013). Braille Quran education: issues and Challenges, International Journal on Quranic Research, 3,4, 79-84.

Official Portal of Special Education 2015. http//uww.moe.gov.my/jpkhas.

Siti Airunnisa Alaui. 2015. Printing Connector of Braille Quran, Utusan Malaysia. 19 Jun.

Siti Maisarah Sheikh Rahim. ( 2011). The Value of Braille Quran to the Disabled People, Utusan Melayu, 17 August.

Siti Nor Azimah Sabaruddin. (2014). Method of Teaching and learning Braille Quran: Case Study at Malaysian Association for the Blind Complex, Brickfields, Kuala Lumpur. Thesis, National University of Malaysia. 